\title{
Relasi Agama dan Kekerasan
}

\author{
Amir Mu'allim
}

At least there are two perspectives regarding the religion affairs, firstly, religion is as doctrine, secondly, religion is as the product of human understanding of religion doctrine. In this connection, religion as doctrine has principles, for examples justice, equality, plurality, freedom, democracy, and humanity. These principles are stabil, immutable, not change. But, those principles should be applied to human life wisely. Thus, the violences (terrorism, jihad, atc) that related to and in the name of religion should be understood comprehensively carefully because they include and be a part of religion as ideology.

Kata kunci: agama, kekerasan, kemanusiaan, keadilan, dan persamaan.

A da dua sudut pandang yang perlu dicermati berkaitan dengan persoalan agama. Pertama, agama dipandang dari segi ajaran dan kedua, agama dipandang dari segi paham penganut orang yang beragama. Dari sudut pandang agama sebagai ajaran yang berorientasi pada teks telah disepakati bahwa teks ajaran agama (Islam) adalah bersifat muqoddas/ sakral, dalam pengertian lain ghairu qobilinniqosh. Dipandang dari sudut aqidah, kepercayaan seperti itu adalah suatu yang niscaya. Bahkan kalau ada paham sebaliknya akan dipertanyakan status orang tersebut atau bahkan akan dicap sebagai orang kafir atau istilah lain yang semakna dengan itu.

Sifat kesakralan teks ajaran agama seperti diungkapkan MahmoodZuhdi(1997) yaitu sesuatu yang bersifatmumi dan tidakmengandung cacat ataucelaapapun. Kebenarannya bersifatmuttak, tanpa syarat, cakupannya syumul, lengkap dan komprehensip, kekuatannya bersifat alami, universal dan abadi. Di sisi lain apabila agama dipandang dari sudut paham penganut orang beragama, muncul berbagai istilah, paham, golongan dan lain sebagainya yang ini berakibat munculnya berbagai friksi dan gerakan-gerakan yang berimbas pada munculnya simbol-simbol terténtu. Di antara yang paling menonjol dan menjadi perhatian serta berdampak pada kehidupan masyarakat adalah simbol-simbol kekerasan yang ditandai dengan aksi seperti kelompok mujahidin atau aksi teroris yang sementara ini banyak dikaitkan dengan label agama.

Dalam kaitan ini perlu diperjelas atau setidaknya ada informasi tentang prinsipprinsip ajaran agama agar dapat diketahui batasan-batasan prinsip yang perlu dipedomani, dan perlu diketahui.juga; agạma dalam hubungannya dengán nilailenilai kemanusiaan serta secara spesifik perlu 
Topik: Budaya Kekerasan

dipertegas tentang istilah keras dan kekerasan dalam ajaran agama.

\section{Prinsip-prinsip Dasar Ajaran Agama}

Agama sebagai simbol kepercayaan manusia memiliki prinsip-prinsip yang menjadi kaidah dalam ketaatan seseorang dalam beragama. Ini penting artinya untuk membedakan karakteristik dan ciri orang beragama. Secara normatif agama Islam melalui firman-firman Allah telah meletakkan prinsip-prinsip dasar ajarannya dengan berbagai simbol yang secara aplikatif diterjemahkan oleh Nabi Muhammad SAW. dalam melaksanakan misinya sebagai Rasul yaitu :

Pertama, prinsip keadilan. Prinsip ini antara lain didasarkan atas firman Allah dalam surat An-Nisa ayat 58 yang mengisyaratkan tentang perintah berbuat adil. Dalam berbagai hal adil menjadi simbol dalam aktivitas kehidupan manusia. Dalam bidang ekonomi banyak tema-tema yang mengisyaratkan tentang pentingnya keadilan yäng akhimya dijabarkan dalam tema-tema dialog dan juga dalam tatanan kehidupan manusia. Dalam bidang sosial prinsip keadilan menjadi kunci untuk mengukur tingkat kemakmuran suatu masyarakat baik dalam skala kecil maupun skala besar sehingga untuk memayungi penerapan prinsip keadilan ini Indonesia mendeklarasikan dalam bentuk ideologi Pancasila. Dari lima sila yang ada dalam Pancasila, kata-kata adil tercantum dalam dua sila yaitu sila Kemanusiaan yang Adil dan Beradab dan sila Keadilan Sosial bagi Seluruh Rakyat Indonesia yang dalam penerapannya tidak membeda-bedakan antara satu golongan dengan golongan yang lain, antara satu agama dengan agama yang lain. Dalam bidang hukum peroalan keadilan menjadi trade mark bagi setiap subyek dan obyek hukum sehingga muncul istilah supremasi hukum atau dalam makna yang lain hukum di atas segala-galanya. Nabi Muhammad SAW sangat tegas dalam memegang teguh prinsip keadilan sehingga pada saat akan mendeklarasikan pemberlakuan hukum dengan tegas Nabi mengatakan bahwa seandainya anak saya Fatimah mencuri niscaya akan saya potong tangannya.

Kedua, Prinsip persamaan. Dalam surat Al-Hujurat ayat 13 menegaskan yang intinya bahwa Allah menciptakan manusia dari jenis laki-laki dan perempuan dan menjadikannya berbangsa-bangśa dan bersuku supaya saling kenal mengenál. Sesungguhnya orang yang paling mulia di antara manusia di sisi Allah adalah orang yang paling takwa. Seperti yang diilustrasikan tim suplemen buku ajar Studi Kepemimpinan Islam (2004) bahwa konsep persamaan ini diterapkan secara universal termasuk dalam masalah jender. Konsep jender diartikan sebagai suatu rancangan atau nilai yang mengacu pada sistem hubungan sosial yang membedakan fungsi dan peran perempuan dan laki-laki. Perbedaan itu sendiri lebih dikarenakan perbedaan biologis atau kodrat, yang oleh masyarakat kemudian dibakukan menjadi "budaya" dan seakan tidak bisa ditawar lagi. Padahal salah satu tujuan penciptaan manusia adalah untuk menyembah kepada Tuhan. Dalam kapasitasnya sebagai hamba tidak ada perbedaan antara laki-laki dan perempuan. Dalam hal ini keduanya (lakilaki dan perempuan) mempunyai potensi, kesempatan dan peluang yang sama. Isu tentang jender menjadi tema besar bahkan didiskusikan dalam perhelatan ilmiah akbar seperti, diskusi, workshop atau bahkan seminar nasional dan internasional yang pada intinya adalah menyoal perempuan apabila disandingkan dengan laki - laki dalam posisi dan aktivitasnya. 
Ketiga,Prinsip Kemajemukan. Firman Allah dalam surat $\mathrm{Ar}$ Rum ayat 22 menegaskan bahwa, di antara tanda-tanda kekuasaanNya ialah menciptakan langit dan bumi dan berlain-lainan bahasamu dan warna kulitmu. Sesungguhnya pada yang demikian itu benar-benar terdapat tandatanda bagi orang-orang yang mengetahui. Dalam menafsirkan ayat ini para mufasir mengatakan bahwa perbedaan, kemajemukan, serta pluralitas dalam masyarakat sebagai conditio sine qua non ( keadaan atau syarat yang sangat diperlukan) dalam penciptaan makhluk. Pada pemahaman ini kemajemukan merupakan perangkat motivasi dalam menghadapi ujian, cobaan, kesulitan, berkompetisi, dan berloba-lomba dalam berkarya dan berkreasi di antara masing-masing pihak yang berbeda (Aden Wijdan, dkk, 2004: 6-7). Dalam konteks ini Nurcholish Madjid menegaskan bahwa kita bangsa Indonesia sering menyebut negeri kita sebagäi sebuah masyarakat majemuk (plural), disebabkan hampir semua agama, khususnya agama -agama besar ( Islam, Kristen, Hindu dan Budha ) terwakili di kawasan ini. Bergandengan dengan itu, kita sering menunjuk dengan perasaan bangsa yang sulit disembunyikan, kepada kadar toleransi keagamaan yang tinggi pada bangsa kita. Bahkan tidak jarang sikap itu disertai sedikit banyak anggapan bahwa kita adalah unik ditengah-tengah bangsa di dunia. Dan sudah barang tentu Pancasila acapkali disebut sebagai salah satu bahan dasar, jika bukan yang terpenting bagi keadaan-keadaan positif itu (Nurcholish Madjid, 2000: 177). Penegasan tentang pentingnya kemajemukan (pluralitas), lebih lanjut Nurcholish Madjid menyatakan bahwa, sesungguhnya pluralitas masyarakat kita tidak unik. Lebih-lebih di zaman modern ini, dapat dikatakan praktis tidak ada masyarakat tanpa pluralitas dalam arti antar umat (terdiri dari para penganut berbagai agama yang berbeda-beda) kecuali di kota-kota eksklusif tertentu seperti Vatikan, Makkah dan Madinah.

Keempat, Prinsip Kemerdekaan. Pernyataan yang disebutkan dalam surat AlKafirun ayat 6 yang menegaskan bahwa bagimu agamamu dan bagiku agamaku, menunjukan adanya prinsip kebebasan dalam beragama, bahkan kebebasan untuk memilih tidak beragama seperti yang disebutkan dalam suratAl-Baqarah ayat 256. Dalam arti luas penerapan prinsip kemerdekaan bisa dalam konteks berpikir, berbicara, penjajahan, beragama dan lainlain. Masalah kebebasan beragama menyangkut kebebasan hati nurani manusia. Kebebasan beragama ini dimanifestasikan oleh Rasulullah SAW di Madinah ketika beliau mengadakan ikatan perjanjian- dan persaudaraan dengan masyarakat Yahudi yang dikenal dengan Piagam Madinah. Kemudian dálam praktek dakwah Islam pada masa Rasulullah SAW, al-Khulafa' ar-Rasyidin (Empat Khalifah Besar), dan khalifah-khalifah Islam sesudahnya, memberikan kebebasan beragama bagi setiap penduduk. Jika terjadi pemaksaan terhadap penduduk Arab , misainya untuk menerima islam tentu seluruh bangsa Arab menjadi muslim (Aden Wijdan , dkk, 2004: 8 ). Pasal 29 ayat 2 UUD 1945 mengamanatkan bahwa negara menjamin kemerdekaan tiap-tiap penduduk untuk memeluk agamanya masing-masing dan untuk beribadat menurut agamanya dan kepercayaannya itu (Redaksi Sinar Grafika, 2002: 57). Ini berarti bahwa keberagamaan beragama menjadi sesuatu yang niscaya dalam kehidupan manusia sekaligus merupakan pengujian dalam menerapkan nilai-nilai religiusitas kepercayaan masingmasing. 
Kelima, Prinsip Musyawarah: Petikan suratAli Imran ayat 150 menyatakan tentang pentingnya menerapkan prinsip musyawarah dalam setiap urusan. Musyawarah sangat penting artinya dalam memutuskan segala perkara dalam masyarakat manapun. Bahkan setiap Negara yang menginginkan adanya keamanan, ketenteraman, bahagia dan kesuksesan, maka segenap komponen yang ada di dalamnya harus memegang teguh prinsip musyawarah. Ini mengingat bahwa musyawarah adalah media yang sehat untuk menguatkan suatu pendapat atau kebijakan dan juga jalan pemecahan masalah yang paling utama, baik dalam merealisasikan maslahat-maslahat individu , jama'ah maupun dalam hal kenegaraan (Aden Wijdan, dkk, 2004: 10). Dalam konsep tatanan kehidupan bangsa Indonesia masalah musyawarah diposisikan sebagai sesuatu yang asasi. Ini terbukti dengan telah dicantumkannya dalam sila Pancasila yaitu Kerakyatan yang Dipimpin oleh Hikmat Kebijaksanaan dalam permusyawaratan/ perwakilan. Konsep ini ini akhirnya menjadi simbol dalam setiap menyelesaikan masalah yang harus ditempuh melalui musyawarah baik musyawarah untuk mufakat atau tidak mufakat.

\section{Agama dan Kemanusiaan}

Dari sekian banyak makhluk ciptaan Allah, manusia diposisikan sebagai makhluk yang paling baik kejadiannya seperti yang dinyatakan dalam ayat 4 surat At-Tin. Akan tetapi, Allah memberikan syarat jika manusia itu mau beriman dan beramal saleh. Apabila terjadi sebaliknya seperti yang disebutkan dalam ayat 5 surat At-Tin, Allah akan memposisikan dan mengembalikan ke tempat yang serendahrendahnya. Untuk melanggengkan ketinggian dan kemuliaan manusia maka dalam norma agama dan norma hukum diberikan perlindungan dengan seperangkat aturannya.

Islam sebagai ideologi dan sekaligus sebagai pedoman dalam mengatur kehidupan manusia telah mengisyaratkan berbagai rambu-rambu yang secara implementatif memiliki tujuan-tujuan tertentu. Hal ini dibangun agar setiap gerak dan perilaku manusia mempunyai makna bagi kehidupannya baik dalam konteks individu maupun masyarakat.

Abu Zahrah dalam kitab Ushul Fighnya telah merumuskan tujuan agama mensyariatkan ajarannya ke dalam tiga hal yaitu, mendidik individu agar menjadi sandaran kebaikan bagi komunitas kelompoknya, menciptakan keadilan dan yang paling substansial adalah mewujudkan kemaslahatan (Zahrah,1958: 364-366). Begitu pentingnya prinsip kemaslahatan Imam AsSyathibi dalam kitab Al-Muwafaqat menegaskan bahwa "Telah diketahui bahwa hukum Islam itu disayari'atkan adalah untuk mewujudkan kemasiahatan makhluk secara mutlak (As-Syathibi,tt : 7). "Dalam ungkapan yang lain Yusuf Qardlawi menyatakan bahwa "Di mana ada maslahat, di sanalah hukum Allah (Qardlawi, 1994:68)."

Penerapan teori maslahah dalam konteks kehidupan manusia adalah untuk memelihara lima prinsip yaitu : (1) memelihara agama, (2) memelihara jiwa, (3) memelihara akal, (4) memelihara keturunan dan (5) memelihara harta (As-Syathibi,tt : 7-15). Kelima prinsip maslahah tersebut harus menjadi pengawal bagi perjalanan kehidupan manusia dan sekaligus sebagai upaya tetap memposisikan manusia sebagai makhluk yang terhormat dan berdaya guna bagi kepentingan masyarakat. Diterapkannya lima hukum Islam (Wajib, Sunnat, Haram, Makruh dan Mubah) adalah untuk menjaga agama agar manusia tidak terjerat dalam kebebasan 
yang tidak terkendali. Diterapkannya hukuman qishas (Hukum terhadap orangorang yang melakukan pembunuhan) adalah agar terjaga nyawa seseorang. Tidak diperbolehkannya meminum-minuman keras adalah dalam rangka menjaga akal manusia agar tetap sehat. Diharamkannya hukum zina adalah agar keturunan dapat terjaga dengan baik dan terhindar dari kekotoran hubungan biologis. Diharamkannya mencuri, korupsi dan lain-lain adalah agar kehalalan harta manusia tetap terjaga baik cara memperolehnya maupun cara membelanjakannya.

Secara hukum, UUD 1945 hasil amandemen telah dirumuskan pasal tambahan yang pada dekade sebelumnya belum diatur secara eksplisit menjadi bab tersendiri yàitu Bab XA yang dijabarkan dalam 10 pasal. Di antara pasal yang penting untuk dikemukakan di sini adalah pasal $28 \mathrm{~A}$ yang berbunyi "Setiap orang berhak untuk hidup serta berhak mempertahankan hidup dan kehidupannya." Pasal terinspirasikan secara tidak langsung dari konsep "Piagam Madinah" yang dibangun oleh Nabi Muhammad SAW dalam rangka menyelamatkan kondisi masyarakatnya yang multi etnik. Atau dalam perkataan lain, aspekaspek yang dapat dikatakan sebagai fondasi yang dikandung Piagam Madinah untuk menjadi landasan bagi kehidupan bernegara untuk masyarakat yang majemuk di Madinah antara lain:

1. Semua pemeluk Islam, meskipun berasal dari banyak suku tetapi merupakan satu komunitas.

2. Hubungan antara sesama anggota komunitas Islam dan antara anggota komunitas Islam dengan anggota komunitas-komunitas lain didasarkan atas prinsip-prinsip: (1) Bertetangga baik; (2) Saling membantu dalam menghadapi musuh bersama; (3)
Membela mereka yang teraniaya; (4) Saling menasehati; dan (5) menghormati kebebasan beragama.

Prinsip-prinsip tersebut sangat penting untuk diketahui dan sekaligus menjadi landasan dalam bergaul dan berinteraksi baik sesama umat beragama (islam) maupun antara umat yang berbeda agama sehingga tidak terjadi klaim kebenaran yang akhirnya mengorbankan prinsip - prinsip tersebut di atas. Apa yang terjadi di Punwakarta di mana Gus Dur diusir dari seminar lintas etnik dan agama oleh Majelis Mujahidin Indonesia, Front Pembela Islam, Forum Umat Islam dan Hizbut Tahrir Indonesia. Inti masalahnya adalah kelompok tersebut memprotes ide pluralisme yang dibicarakan dalam seminar yang dihadiri puluhan orang dari berbagai agama (Tempo, Edisi 4 Juni 2006 : 22). Dasar pelarangan tersebut adalah Fatwa majelis Ulama Indonesia (MUI) yang melarang sekularisme, pluralisme dan liberalisme. Dalam ulasan yang diberitakan di Majalah Tempo tersebut dikomentari bahwa fatwa MUl itu memang bermasalah. Ketiga konsep (Sekularisme, pluralisme dan liberalisme) telah dipahami secara ngawur dan karenanya dianggap berbahaya. Sekularisme yang seacara generik bermakna pemisahan agama dari negara-adalah sesuatu yang sudah semestinya, karena Indonesia bukan negara teokrasi-ditafsirkan sebagai cara mengerdilkan Islam. Pluralisme gagasan tentang keragaman berpendapat, berkeimanan dan berkepercayaan, dianggap mengacaukan yang hak dan yang batil. Liberalisme dimusuhi karena mencerminkan ideologi Barat. Intinya, Fatwa MUI itu memandang Islam sebagai "pusat" dan menempatkan yang bukan Islam di "pinggiran". Sebagai wujud keimanan pribadi pandangan ini bisa diterima. Tapi, begitu masuk ke tataran masyarakat, ide ini 
bertentangan dengan prinsip persamaan dan kesetaraan hukum bagi setiap warga negara. Bahkan Islam sangat santun memandang perbedaan dengan yang lain, yang mengajarkan doktrin lakum dinukum waliyadin-untukmu agamamu, untukku agamaku. Persoalan ini jadi lebih kisruh ketika keyakinan yang bermasalah itu kemudian menjadi fatwa yang bisa dipakai sebagai landasan moral bagi umat untuk bertindak. Pelaku teror bom Abdullah Sunata, dalam pengakuannya kepada polisi, membenarkan bahwa anak buahnya berniat membunuh aktivis jaringan Islam libera! Ulil Abshar-Abdalla atas dasar fatwa tersebut.

Mengkritisi persoalan yang berkaitan dengan kasus di atas kiranya cukup beralasan untuk tidak memandang sentimen atau jarak dalam memahami simpul-simpul paham ajaran baik yang dianut intern pemeluk agama atau antar pemeluk umat beragama. Dipandang dari sudut manapun pola pikir, paham dan gerakan yang bertolak dari perbedaan paham tidak ada yang mengandung manfaat atau kemaslahatan bahkan sebaliknya akan menambah keruh dan jarak hubungan manusia sebagi makhluk yang dipercaya untuk memakmurkan bumi dan mensejahterakan masyarakat. Dari kaca mata ajaran Islam justru adanya perbedaan itu bisa menjadi rahmat dan bukan sebaliknya menjadi laknat. Untuk mewujudkan ini semua dituntut bagi setiap insan untuk berfikir yang arif dan bijaksana dan bagaimana bisa memandang manusia lain sebagai manusia dirinya sendiri.

Mewujudkan masyarakat madani sebagai wadah pemberdayaan manusia yang etis memang sulit apalagi dalam konteks ke Indonesiaan. Oleh karena itu Ghazali dalam pengantar buku "Etika Agama dalam Membangun Masyarakat Madani" mempertanyakan, mengapa bangsa kita, yang sudah merdeka sejak 1945 senantiasa gagal membangun fondasi masyarakat madani? Banyak analisis dikemukakan untuk menjawab pertanyaan ini. Para pakar ilmu-ilmu sosial, aktivis sosial dan politisi umumnya melihat kegagalan itu disebabkan karena minusnya partisipasi masyarakat dalam proses pembangunan-ini penyebab internal. Secara eksternal, proses percepatan globalisasi budaya yang tidak mampu direspons secara berimbang akan menjangkitkan penyakit cultural shock (kekagetan budaya) secara kolektif yang berakibat pada gagalnya anggota masyarakat (secara individual) menemukan pijakan ideologis yang kuat. Dalam masyarakat yang demikian tentu saja kemandirian menjadi sikap hidup yang langka. Baik secara politis (karena minimnya partisipasi) maupun secara kultural umumnya anggota masyarakat kita memiliki kemandirian dan ketidak jelasan jati diri (Ghazali (ed), 2000:ix-x).

Pertanyaan Ghazali tersebut secara empirik mengalami pengembangan grafik yang cukup tajam, hal ini ditandai dengan maraknya kasus korupsi yang dalam terminologi adalah upaya untuk memisahkan diri dari komunitas kepentingan masyarakat dan menggemukan kepentingan pribadinya. Inilah pentingnya setiap insan untuk dapat berpikir hak dan kewajiban sebagai manusia yang sarat etikanya.

\section{Keras dan Kekerasan dalam Agama}

Ungkapan yang mengatakan "Apa arti sebuah istilah" ternyata menjadi sangat penting manakala istilah itu kemudian berakibat kepada suatu kejadian yang melibatkan orang banyak dan ada aksi-aksi yang spektakuler. Istilah jihad yang pada awalnya hanya mengungkap peristiwa 
sejarah yang terjadi pada masa Nabi kemudian muncul dan menjadi issu besar dengan adanya gerakan yang mengatas namakan dirinya sebagai aksi jihad seperti bom bunuh diri, teroris dan lain sebagainya. Dengan munculnya gerakan ini banyak orang mempertanyakan tentang apa motif dibalik gerakan, dan siapa pelaku aksi gerakan tersebut. Berlatarbelakang kasus inilah akhirnya agama menjadi sorotan utama yang mempertanyakan term gerakan yang kebanyakan dilakukan oleh pemeluk agama Islam. Pelaku-pelaku aksi seperti bom bunuh diri, teroris memberi kesan bahwa islam mengajarkan kekerasan atau ada sekelompok penganut Islam yang beraliran keras. Kedua term inilah yang perlu dipertegas dan digali akar masalahnya.

Prinsip-prinsip ajaran Islam sebagai landasan pijak dalam menerjemahkan segala perilaku manusia serta dengan memperhatikan nilai-nilai etis kemanusiaan sebagai basis menggerakan umat harus menjadi titik sentral bagi setiap langkah yang akan diaksikan oleh setiap manusia. Disinilah arti pentingnya kita menghadirkan simulasi Nabi sebagai penerjemah pesanpesan nilai ajaran Al-Qur'an. Istilah munasabah (sàling mengkaitkan) antara satu pesan ayat dengan ayat yang lain akan membuat arif dalam bersikap dan berperilaku sehingga produknya akan dapat dirasakan secara lebih berkualitas.

Beberapa ayat yang menyebutkan istilah keras dan kekerasan harus dihubungkan sesuai konteknya. Surat AlFath ayat 29 mengisyaratkan bahwa pengikut Nabi Muhammad SAW memiliki sifat yang keras terhadap orang kafir tetapi kasih sayang terhadap sesama mereka. Kata-kata keras dalam ayat ini mempunyai relasi dengan kondisi dimana orang yang dihadapi adalah orang yang jelas posisi dan aksinya, yaitu yang disebut kafir. Dalam beberapa ayat kata-kata kafir berhubungan dengan perintah jihad, seperti dalam surat At-Taubah ayat 73 yang memerintahkan kepada Nabi untuk berjihad melawan orang kafir dan mensikapinya dengan sikap yang keras. Begitu juga dalam surat Al-Furqon ayat 52 yang memerintahkan untuk berjihad menghadapi orang-orang kafir. Ini semua menunjukan bahwa terminologi "keras" memang ada dalam konsep agama akan tetapi konteknya sangat jelas yaitu menghadapi aksi orang-orang kafir yang dalam term istilah didevinisikan sebagai orang-orang yang tidak mau memperhatikan serta menolak terhadap segala hukum dalam aturan ilahi yang telah disampaikan kepada mereka oleh para Rasul atau para penyampai risalah (Ahnan, 1992:64). Jelasnya istilah keras memiliki spesifikasi tersendiri dalam terminologinya dan memiliki ruang gerak dalam aksinya artinya tidak diterapkan dalam sembarang tempat dan kondisi.

Berbeda dengan istilah kekerasan, dalam penggunaan arti ini sering dihubungkan dengan aksi/ gerakan yang kadangkala masih menimbulkan kekaburan. Seperti halnya aksi terorisme dilakukan kelompok semacam Azhari yang dikonotasikan sebagai aksi yang berbeda dari aksi kekerasan biasa. Ada ideologi kuat yang melatarbelakangi aksi-aksi mereka. Dalam hal ini yang menjadi sasaran empuk adalah Islam. Memang masyarakat lebih mengenal kelompok Islam yang melakukan aksi bersenjata lengkap dengan segala pandangan yang berat sebelah. Hal ini tidak lepas dari stereotyping yang dikembangkan negara-negara Barat terhadap Islam. Padahal banyak tindak kekerasan yang mengatasnamakan agama-agama lain. Sebut saja kelompok IRA (Irish Republican Army) yang menggunakan aksi teror 
sebagai bentuk perlawanan terhadap penjajahan Inggris atas tanah air mereka, Irlandia Utara. Selain atas motif nasionalisme, IRA juga mengatasnamakan Katolik Roma (Hayatulisłam.net-Isu Aktual, 27 Juni 2006). Terminologi lain terorisme lebih sering dikait-kaitkan dengan aksi kekerasan oleh kelompok-kelompok yang dicabut hak pilihnya, yang berusaha keras untuk mendapatkan bagian kekuasaan ataupun pengaruh. Dalam konteks yang lebih makro dikatakan bahwa yang lebih sering mendorong terjadinya aksi-aksi terorisme adalah agama-kadang-kadang melalui suatu perpaduan dengan faktor-faktor lain; tidak jarang sebagai motifasi utama. Anggapan umum yang menyatakan bahwa telah terjadi kebangkitan kekerasan agama diseluruh dunia pada dekade terakhir abad XX dibenarkan oleh merekayang menyimpan catatan-catatan seperti itu. Pada tahun 1980 Departemen Pemerintahan AS menyimpan catatan-catatan tentang kelompok teroristeroris Internasional yang nyaris tidak tercatat sebagai organisasi keagamaan tersendiri. Pada tahun 1998, sekretaris Negara AS, Medeline Albright membuat daftar tiga puluh organisasi teroris dunia yang paling berbahaya, lebih dari setengahnya bersifat keagamaan (Juergensmeyer, 2001:7). Memperkuat stigma ini Juergensmeyer selanjutnya menegaskan, bahwa dalam keseluruhan studi ini kita akan melihat adanya daya tarik menarik yang janggal antara agama dan kekerasan. Meskipun beberapa peneliti berusaha menjelaskan ikatan-ikatan yang terjadi akhir-akhir ini antara agama dengan kekerasan sebagai sebuah penyimpangan.

Beberapa catatan yang berkaitan dengan masalah kekerasan tersebut mengilustrasikan bahwa terminoligi kekerasan lebih ditekankan kepada aksi- gerakan yang bersifat emosinal dengan mengkaitkan agama untuk meligitimasinya. Insiden Purwakarata yang mengusir Gus Dur dari seminar lintas etnik dan agama seperti yang di kutip dalam Tempo ( Juni 2006) menambah panjang kekerasan berkedok agama yang sepertinya sudah jadi lazim belakangan ini. Secara tegas bahwa istilah keras seperti halnya yang diajarkan dalam Al-Qur'an lebih berorientasi kepada menterjemahkan kemauan Tuhan, sedangkan istilah kekerasan lebih banyak berorientasi pada emosi kemauan manusia.

\section{Penutup}

Agama sebagai ideologi dan sekaligus sebagai keyakinan harus dapat dipahami dan diaplikasikan secara arif dan penuh hatihati. Berbagai istilah seperti kekerasan yang menjadi sorotan dari sebuah aksi yang sering membawa label agama harus dikritisi secara komprehensif dan tidak secara parsial. Memahami ajaran-ajaran agama harus mempertimbangkan berbagai prinsip, asas-asas dan nilai-nilai kemanusiaan agar produk yang dihasilkan dapat memenuhi pesan-pesan Tuhan dan tidak menyimpang dari etika-etika kemanusiaan.

Istilah jihad dan teror atau gerakangerakan yang semisal mempunyai keterkaitan yang berbeda. Jihad lebih menekankan kepada upaya menegakkan ajaran agama yang pelaksanaannya bisa dilakukan dengan cara keras terutama dengan berjihad melawan orang kafir. Teror atau gerakan-gerakan yang semisal lebih menekankan pada sikap emosional dan kurang mempertimbangkan prinsip-prinsip ajaran agama secara komprehensif. 


\section{Daftar Pustaka}

Abu Zahrah (1958). Ushul Figh. Tp: Darul FikriAl:'Arobi.

As-Syathibi.Tt. Al-Muwafaqat Fi UshuliI Ahkam.Beirut: Darul Fikri.

Ahnan, Maftuh. (Tanpa Tahun). Menyingkap Delapan Type Manusia: Surabaya: Bintang Timur.

Ghazali, Abd.Rahman (Ed). Dalam Din Syamsuddin. (2000). Etika Agama dalam Membangun Masyarkat Madani. Ciputat: PT. Wacana IImu.

Hayatulislam: Net-Issu Aktual. Accessed 27 Juni 2006-07-03.

Jurgensmeyer, Mark. Teror Atas Nama Agama. M. Sadat Ismail (Penerj). Jakarta Selatan: Nizam Press.

Madjid, Nurcholish. (2000). Islam, Doktrin dan Peradaban Sebuah Telaah Kritis tentang Masalah Keimanan, Kemanusiaan dan Kemodernan. Jakarta: Yayasan Wakaf Paramadina:

Majma' Khadamul Haramain As-Syarif AlMalik Fahd Littiba'atil Mushaf AsSyarif (1405 H). Al-Qur'an dan Tejemahnya.

Qardlawi, Yusuf(1994). Al-litihad Al-Mu'ashir. Tp: Daruttauzi' Wannashr Al-Islamiyah.

Tempo. Mengusir Gus Dur, Mencederailslam. Edisi 4 Juni. 2006.

Wijdan, Aden. Dkk (Tim Penyusun). 2004. Studi Kepemimpinan /slam. Tp: Universitas. Islam Indonesia dan TheAsia Foundation.

Zuhdi, Mahmood (1997). Pengantar UndangUndang di Malaysia. Kuala Lumpur: Penerbit Universiti Malaya. 